\title{
Epidemiology of Barrett's oesophagus and oesophageal adenocarcinoma
}

\section{Epidemiologia przełyku Barretta i gruczolakoraka przetyku}

\author{
Nancy Perez, William Taylor \\ Department of Gastroenterology, St. Joseph Medical Center, University of Washington, WA, USA \\ Head of the Department: Prof. Walter Brown
}

Medical Studies/Studia Medyczne 2019; 35 (1): 61-68

DOI: https://doi.org/10.5114/ms.2019.84053

\begin{abstract}
Key words: gastro-oesophageal reflux disease, risk factors, oesophageal adenocarcinoma, epidemiology, Barrett's oesophagus.

Słowa kluczowe: choroba refluksowa żołądkowo-przełykowa, czynniki ryzyka, gruczolakorak przełyku, epidemiologia, przełyk Barretta.
\end{abstract}

\begin{abstract}
Barrett's oesophagus is a condition characterised by metaplastic changes in the oesophagus and is a precursor to oesophageal adenocarcinoma. Oesophageal adenocarcinoma is recognised as being responsible for an increasing number of cancerrelated deaths, especially in the western world. A deluge of risk factors have been described in the literature. Some of the important ones include gastroesophageal reflux disease, Helicobacter pylori infection, lifestyle factors like alcohol consumption, smoking, and dietary factors, and metabolic diseases like obesity. It also poses challenges in diagnosis and treatment despite recent advances in diagnostics, surgery, and other therapies. This is a narrative review of the findings of multiple studies that were retrieved from electronic databases like PubMed, Google Scholar, Scopus, Medline, Embase, and Cochrane. We summarise the current knowledge regarding the epidemiology and various risk factors for the development of Barrett's oesophagus and oesophageal adenocarcinoma.
\end{abstract}

\section{Streszczenie}

Przełyk Barretta charakteryzuje się występowaniem zmian metaplastycznych w przełyku i jest stanem przedrakowym przełyku. Gruczolakorak przełyku odpowiada za coraz większą liczbę zgonów z powodu raka, zwłaszcza na Zachodzie. W piśmiennictwie wskazano wiele czynników ryzyka. Do najważniejszych z nich należą: choroba refluksowa przełyku, zakażenie Helicobacter pylori, czynniki związane ze stylem życia, takie jak spożywanie alkoholu, palenie tytoniu i czynniki żywieniowe, oraz choroby metaboliczne, takie jak otyłość. Schorzenie to stwarza problemy w zakresie diagnostyki i leczenia pomimo dokonanych ostatnio postępów w dziedzinie diagnostyki, leczenia operacyjnego i innych terapii. W artykule przedstawiono przegląd wyników wielu badań, które pobrano z elektronicznych baz danych, takich jak PubMed, Google Scholar, Scopus, Medline, Embase i Cochrane. Podsumowano także aktualną wiedzę na temat epidemiologii i czynników ryzyka rozwoju przełyku Barretta i gruczolakoraka przełyku.

\section{Introduction}

Barrett's oesophagus (BO) is a medical condition that encompasses metaplastic changes in the epithelial lining of the lower oesophagus, whereas the normal stratified squamous epithelium is replaced by simple columnar with goblet cells [1]. The principle aetiology behind BO is gastro-oesophageal reflux disease (GORD), which is globally defined as reflux of stomach contents leading to troublesome symptoms and/ or complications [2]. Of them, the two main complications are $\mathrm{BO}$ and reflux oesophagitis $[3,4]$. In addition, males, obese persons, and those over 50 years old have a possible risk of developing $\mathrm{BO}$ [5-7]. However, patients may complain of heartburn, difficulty swallowing, vomiting blood, pain beneath the sternum, and less commonly weight loss [1]. The diagnosis of $\mathrm{BO}$ can be made by upper gastrointestinal endoscopy, and histological examination of the biopsy discloses the metaplasia [8].

It has been estimated that patients with $\mathrm{BO}$ progress to oesophageal adenocarcinoma (OAC) 30-125 times more than the general population [9-11]. During the 1960s and 1970s, only about 5\% of OAC patients survived at least 5 years after being diagnosed, whereas now the 5 -year survival rate is about $20 \%$ 
[12]. The mortality rate of $\mathrm{OAC}$ is $85 \%$, and in many regions of the western world, the incidence has been rising at a worrisome rate [13-16]. Screening and surveillance programs are vital to identify the high-risk population and to understand the epidemiology of the disease. Thus, several studies have been investigating the epidemiology of BO and OAC [2, 17-19]. Our study aimed to thoroughly review the incidence, prevalence, and risk factors associated with $\mathrm{BO}$ and OAC.

\section{Incidence and prevalence of Barrett's oesophagus}

First of all, patients with BO may complain of reflux symptoms such as heartburn, difficulty swallowing, haematemesis, and pain below the sternum. Nevertheless, the precise evaluation of the incidence and prevalence of $\mathrm{BO}$ and $\mathrm{OAC}$ is unattainable because patients with BO may report no symptoms. Therefore, the number of endoscopic autopsy-dependent diagnosis studies has been increasing dramatically over the years. In the United States, this has been emphasised in a prospective study including a volunteer population, in which patients who were primarily involved for colonoscopy agreed to undergo upper endoscopy. This may implicate selection bias. However, about $8 \%$ of subjects with previous history of heartburn exhibited the finding of BO through endoscopic examination. In contrast, only $6 \%$ with no history of reflux symptoms were diagnosed with BO [20-24].

Similarly, in another study in the United States but with more robust methodology through randomised screening procedures, patients with $\mathrm{BO}$ were recognised and considered for inclusion [25]. Interestingly, the overall incidence rate of $\mathrm{BO}$ in patients with no reflux symptoms was $20 \%$ compared to $15 \%$ in patients reporting no symptoms [26, 27]. In a population based study in the United States, the incidence of clinically diagnosed BO increased 28-fold between 1965 and 1997 compared to endoscopic autopsy-dependent diagnosis, which increased 22 -fold in the same time frame. In the same study, the incidence of OAC increased 10-fold, and most cases reported no previous history of BO, suggesting that many patients with BO experienced no symptoms [21]. They deduced that the incidence and prevalence of $\mathrm{BO}$ with clinical signs had increased concurrently with the mounting application of endoscopic examinations [21, 28]. In another study in the Netherlands including 100,000 patients, and irrespective of the mounting number of upper endoscopic examinations being carried out, the incidence of BO raised from $14.3 \%$ of subjects in 1997 to $23.1 \%$ of subjects in 2002 . Also, the incidence of adenocarcinoma remarkably increased from $1.7 \%$ person-years in 1997 to 6\% person-years in 2002 [29].

Regarding the prevalence, the long-segment BO prevalence was detected in 376/100,000 cases, sugest- ing that only a few cases could be recognised clinically [9, 30-34] In Sweden, researchers carried out upper gastrointestinal endoscopy on 1000 randomly allocated participants, aiming to estimate the prevalence of $\mathrm{BO}$ in the general Swedish population. Among them, $16(1.6 \%)$ cases were diagnosed with $\mathrm{BO}$, and $5(0.5 \%)$ cases exhibited long-segment BO [18]. In another European study, 1533 Italian adults were counted for upper gastrointestinal endoscopy, and the prevalence rate was $1.3 \%$. Out of them, around $46.2 \%$ experienced no reflux symptoms [2]. In contrast to western countries, the prevalence of $\mathrm{BO}$ in the Far East is relatively low. However, in a Korean study, and among 992 patients allocated, 108 cases were diagnosed as short-segment $\mathrm{BO}$, and only three cases were diagnosed as long-segment BO. As usual, the diagnostic method comprised of upper endoscopy. However, only 36 (3.6\%) subjects met the histological standards of BO [17].

\section{Age, sex, and ethnicity variations in patients with Barrett's oesophagus}

Barrett's oesophagus is diagnosed on average in the sixth to seventh decade of life but may develop far earlier. Males are more commonly diagnosed with BO compared to females, with a ratio of $2.5: 1[35,36]$ A study by van Blankenstein et al. showed that males on average developed $\mathrm{BO}$ about 20 years earlier when compared to females, with a ratio of males to females $2: 1$. However, the ratio of men to women approached $4: 1$ in younger adults [35].

Recently, in a case-control study 237 endoscopydependent diagnosed patients were examined to inspect the effect of waist-to-hip ratio (WHR) on the risk of BO. This study revealed that more patients with BO had a high WHR (92.4\%) when compared to endoscopy controls (79.5\%). The WHR was not high in black or Hispanic participants. However, a significant association with $\mathrm{BO}$ was discovered in whites $(\mathrm{OR}=2.5$; 95\% CI: 1.2-5.4) [37] In the UK, one cross-sectional study was carried out to explore the risk of $\mathrm{BO}$ with regard to ethnicity. A total of 20,310 patients were included in the statistical analysis and revealed that $\mathrm{BO}$ is more common in white Caucasians $(2.8 \%, n=$ 14,095) than in South Asians $(0.3 \%, n=5190)$ [38]. Moreover, in a cross-sectional analysis, white Caucasians had a remarkably higher association with BO $(6.1 \%, n=792)$ compared to Hispanics $(1.7 \%$, $n=466)$, and the results were statistically significant $(p=0.0002)$ [39].

\section{Epidemiology of oesophageal adenocarcinoma}

Oesophageal cancer ranks seventh in terms of incidence and sixth in mortality overall (Figure 1). The global distribution of oesophageal cancer differs markedly from that of most other adult tumours. Men 


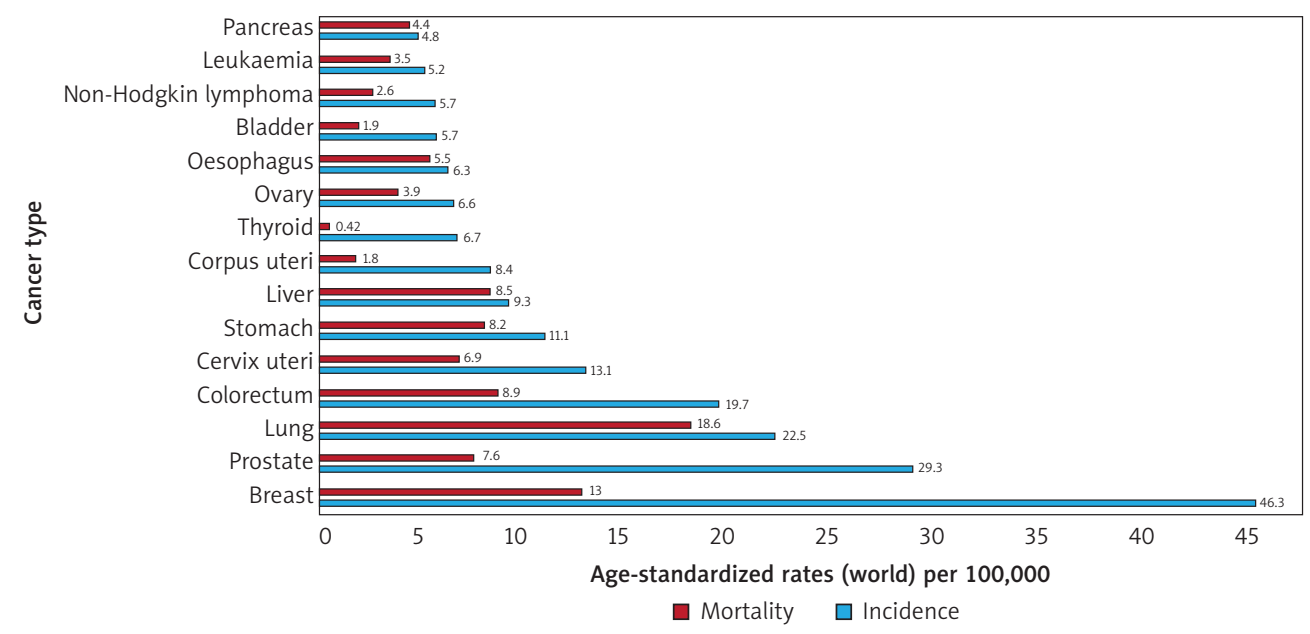

Figure 1. Estimated age-standardised incidence and mortality rates in 2018, worldwide, for both sexes, at all ages

account for $70 \%$ of cases of oesophageal cancer. Compared to females, males have a $2-3$-fold increase in incidence and mortality [40-43].

About $87 \%$ of all oesophageal cancers globally are squamous cell carcinoma (SCC) of the oesophagus [44]. Only $11 \%$ of all oesophageal cancers are OACs, with an increased burden seen in Northern America, Northern and Western Europe, and Oceania [44, 45]. The OAC represents the majority of oesophageal cancer cases in high-income countries, with GORD and obesity being the key risk factors [41]. Smoking and heavy drinking of alcohol are the main risk factors for SCC of the oesophagus. The incidence of SCC of the oesophagus is decreasing worldwide, mainly due to a decline in smoking and alcohol consumption in high-income countries and dietary improvements in high-risk Asian countries. However, in those same countries, the incidence of OAC is on the rise, mainly due to increased obesity, increased GORD, and possibly due to reductions in $\mathrm{H}$. pylori infections [46].

Caucasian men have the highest incidence of OAC, with a male-female ratio approaching $8: 1$ in Caucasians [47]. The same ratio in African-Americans was $3: 1$ and in Latinos $7: 1$ [48]. Surveillance, Epidemiology, and End Results (SEER) Program data suggest that the ratio of OAC cases in Caucasians when compared to African-Americans is approximately $5: 1$ [49].

Improvement in overall survival has been substantial in patients with invasive OAC over the last few decades [50]. A study in the US showed that the overall increase in 5-year survival in patients with oesophageal cancer from the 1990s to the 2000s increased from $18 \%$ to $22 \%$ [51]. Another study based on the European registry (EUROCARE-5) also showed that 5-year overall survival of oesophageal cancer patients increased from $10 \%$ in $1999-2001$ to $13 \%$ in 2005-2007 [52]. In another study in China, the 5-year relative age-standardised survival rate for oesopha- geal cancer was 21\% in 2003-2005 [53]. Patients who underwent oesophagectomy had increased survival for all stages. Patients aged $<65$ years had better survival when compared to patients aged $\geq 65$ years [50] A recent population-based, nationwide study in Sweden has shown that from 1990-1994 to 2010-2013, the relative 5-year survival increased from $12 \%$ to $15 \%$ for OAC [54].

\section{Overview of the risk factors of Barrett's oesophagus and oesophageal adenocarcinoma}

Several epidemiological studies examined the predisposing factors for $\mathrm{BO}$ and $\mathrm{OAC}$, and they have shown fundamental unanimity on multiple modifiable and non-modifiable risk factors. Herein, we seek to recapitulate the evidence from the enormous literature and discuss the important risk factors that predispose to $\mathrm{BO}$ and OAC $[55,56]$.

\section{Gastro-oesophageal reflux disease}

The main risk factor for OAC is GORD. Approximately $10-15 \%$ of patients with GORD will develop BO. The chronic injury produced by repeated reflux episodes leads to this metaplastic transformation and involves genetic mutations that can lead to a malignant transformation. The sequence of $\mathrm{BO}$ metaplasia-dysplasia-invasive carcinoma ultimately leads to the development of OAC $[57,58]$. A meta-analysis of five studies showed that at least weekly symptoms of GORD increased the odds of OAC 5-fold, and daily symptoms increased the odds seven fold, when compared with individuals without symptoms or with less frequent symptoms [59]. A pooled analysis from the Barrett's and Esophageal Adenocarcinoma Consortium (BEACON) study showed that increasing heartburn duration was associated with increasing OAC 
risk with odds ratios of 2.80, 3.85, and 6.24 for the duration of symptoms of $<10$ years, 10 to $<20$ years, and $\geq 20$ years, respectively [60]. Earlier age at onset of recurrent GORD symptoms is associated with high risk for BO, especially if the first reported symptoms are at age $<30$ years (odds ratio (OR) 15.1, 95\% confidence interval (CI): 7.91-28.8) [61]. Endoscopic screening to detect dysplasia is recommended for patients with $\mathrm{BO}$.

\section{Smoking}

Smoking has been shown to increase the risk of OAC, particularly in patients with $\mathrm{BO}$ [62]. A pooled analysis of 12 studies from the BEACON study showed that the risk of OAC or cancer of the oesophagogastric junction was 2.08 times higher in smokers than in a control group [60]. The risk increased with the number of pack-years smoked, and it was reduced after smoking cessation but not to the level of nonsmokers. Compared with never-smokers, the pooled relative risk (RR) for oesophageal and gastric cardia adenocarcinoma was 1.6 for ever-smokers, 2.32 for current smokers, and 1.62 for ex-smokers [63]. However, a recent meta-analysis of 52 studies showed that the risk of OAC was only slightly lower among former smokers ( $\mathrm{RR}=1.66,95 \% \mathrm{CI}: 1.48-1.85)$ than among current smokers $(\mathrm{RR}=2.34,95 \% \mathrm{CI}: 2.04-2.69)$ by non-smokers as a reference. It also showed that smoking cessation for 20 years or more strongly decreases the risk of oesophageal SCC in a time-dependent manner, particularly in western populations, while it has limited influence on the risk of OAC $(R R=0.72$, 95\% CI: 0.52-1.01) [64].

\section{Alcohol}

Unlike oesophageal SCC, where alcohol is a strong risk factor, studies have not shown an association between the amount of alcohol consumed and the risk of OAC development. A meta-analysis of four cohorts and 20 case-control studies concluded that there was no association between alcohol consumption and OAC risk, even at higher levels of consumption. The RR for drinkers versus non-drinkers was 0.96 vs. 0.87 , respectively [65]. Findings from the BEACON study showed that alcohol consumption was not a risk factor for $\mathrm{BO}$ or progressing from $\mathrm{BO}$ to $\mathrm{OAC}[66,67]$.

\section{Obesity and metabolic syndrome}

The incidence of $\mathrm{BO}$ and $\mathrm{OAC}$ has increased rapidly in the past 40-50 years in western countries, parallel with rapid increases in the rate of obesity $[68,69]$. Obesity has been linked to a higher risk for $\mathrm{OAC}$ and to $\mathrm{BO}$, a predisposing lesion for $\mathrm{OAC}[70,71]$. For every $1 \mathrm{~kg} / \mathrm{m}^{2}$ increase in body mass index (BMI) OAC risk increased by $16 \%$ and $\mathrm{BO}$ risk increased by $12 \%$ [71]. A pooled analysis from the International
BEACON Consortium showed that the association of OAC and oesophagogastric junction adenocarcinomas increased directly with increasing BMI. Compared to a BMI of $<25 \mathrm{~kg} / \mathrm{m}^{2}$ a BMI of $30.0-34.9 \mathrm{~kg} / \mathrm{m}^{2}$ was associated with a two-fold increased risk of OAC and 4- to 5 -fold risk with $\mathrm{BMI} \geq 40.0 \mathrm{~kg} / \mathrm{m}^{2}[72,73]$.

Analysis of the SEER database in the United States found OAC to be significantly associated with metabolic syndrome $(\mathrm{OR}=1.16,95 \% \mathrm{CI}$ : 1.06-1.26) compared with population controls [74]. Being overweight in early adulthood (age 20 years) and weight gain later in life were each associated with increased risks of OAC [75]. Obesity may represent an indirect risk factor for both $\mathrm{OAC}$ and $\mathrm{BO}$ because it increases the risk of GORD by mechanical mechanism effects, which include disruption of the gastro-oesophageal junction reflux barrier [76, 77]. Kubo et al. found that waist circumference a risk factor for $\mathrm{BO}$ among both men and women, even after adjustment for BMI [78, 79]. This was supported by a study that used CT scans to measure adipose tissue and showed that a large amount of visceral abdominal adipose tissue is associated with a significant increase in the risk of $\mathrm{BO}$ when compared to subcutaneous adipose tissue [80].

\section{Helicobacter pylori infection}

The prevalence of $\mathrm{H}$. pylori infection has decreased in populations where the incidence of OAC has increased, suggesting a potential inverse relationship. A meta-analysis of 28 studies showed that there was a significant inverse association between H.pylori infection (pooled OR $=0.57 ; 95 \% \mathrm{CI}$ : 0.44-0.73) and OAC (pooled OR $=0.57,95 \%$ CI: 0.44-0.73) [81]. In people who had frequent GORD symptoms, BO risk was almost $80 \%$ lower among $\mathrm{H}$. pylori-positive patients than in those negative for H. pylori [61]. Studies have shown an inverse statistically significant relationship of $\mathrm{H}$. pylori infection with both $\mathrm{OAC}$ and $\mathrm{BO}$, which might suggest a protective role of the infection in these entities, although this has been controversial [82]. The BEACON study showed that H. pylori infection was inversely associated with the risk of BO [83].

\section{Medications}

Multiple studies have shown that aspirin and nonsteroidal anti-inflammatory drugs (NSAIDs) reduced the risk of OAC [84]. A study by Liao et al. showed that individuals who used NSAIDs had a statistically significant reduced risk of OAC, with an approximately $40 \%$ reduction in those who used it frequently (daily or more frequently) and for a longer duration ( $\geq 10$ years) [85]. However, a recent study by Thrift et al. showed that regular (at least once weekly) use of any NSAIDs was not associated with the risk of BO [86]. Studies have shown that regular statin use was 
inversely associated with the development of OAC and BO [87-90]. Studies have also shown that use of lower oesophageal sphincter relaxing drugs like nitroglycerin, anticholinergics, and $\beta$-adrenergic agonists was positively associated with risk for OAC [91, 92]. A meta-analysis of seven observational studies showed that the use of proton pump inhibitors was associated with a decreased risk of OAC and/or highgrade dysplasia in patients with $\mathrm{BO}$ [93-95]. A recent meta-analysis of nine studies showed that long-term use of proton-pump inhibitors in patients with $\mathrm{BO}$ had no protective effects against the development of OAC or high-grade dysplasia [96]. Use of oral bisphosphonates has been linked to OAC and SCC of the oesophagus in post-marketing surveillance in one study [97]. However, a large cohort study done in the United Kingdom found that the use of oral bisphosphonates was not significantly associated with incident oesophageal cancer [98].

\section{Conclusions}

The OAC is recognised as being responsible for an increasing number of cancer-related deaths, especially in the western world. Significant global strides have been made in the global prevention and treatment of OAC. While prevention efforts are focused on $\mathrm{BO}$ screening and surveillance, the main challenge is to identify $\mathrm{BO}$ patients at highest risk of progression to OAC, so that they can be offered appropriate follow-up and therapy. Diet and lifestyle modification are also the most effective means of preventing OAC, especially in the developed world. Analysis of OAC and $\mathrm{BO}$ epidemiology may be the cornerstone of developing future cancer control strategies.

\section{Conflict of interest}

The authors declare no conflict of interest.

\section{References}

1. Shaheen NJ, Richter JE. Barrett's oesophagus. Lancet 2009; 373: 850-861.

2. Zagari RM, Fuccio L, Wallander MA, Johansson S, Fiocca R, Casanova S, Farahmand BY, Winchester CC, Roda E, Bazzoli F. Gastro-oesophageal reflux symptoms, oesophagitis and Barrett's oesophagus in the general population: the Loiano-Monghidoro study. Gut 2008; 57: 1354-1359.

3. Vakil N, van Zanten SV, Kahrilas P, Dent J, Jones R; Global Consensus Group. The Montreal definition and classification of gastroesophageal reflux disease: a global evidence-based consensus. Am J Gastroenterol 2006; 101: 1900-1920.

4. Rawla P, Sunkara T, Thandra KC, Gaduputi V. Efficacy and safety of budesonide in the treatment of eosinophilic esophagitis: updated systematic review and meta-analysis of randomized and non-randomized studies. Drugs R D 2018; 18: 259-269.

5. Singh S, Sharma AN, Murad MH, Buttar NS, El-Serag HB, Katzka DA, Iyer PG. Central adiposity is associ- ated with increased risk of esophageal inflammation, metaplasia, and adenocarcinoma: a systematic review and meta-analysis. Clin Gastroenterol Hepatol 2013; 11: 1399-1412. e1397.

6. Rubenstein JH, Mattek N, Eisen G. Age- and sex-specific yield of Barrett's esophagus by endoscopy indication. Gastrointest Endosc 2010; 71: 21-27.

7. Rubenstein JH, Morgenstern H, Appelman H, et al. Prediction of Barrett's esophagus among men. Am J Gastroenterol 2013; 108: 353-362.

8. Flejou J. Barrett's oesophagus: from metaplasia to dysplasia and cancer. Gut 2005; 54: i6-i12.

9. Cameron AJ, Ott BJ, Payne WS. The incidence of adenocarcinoma in columnar-lined (Barrett's) esophagus. N Engl J Med 1985; 313: 857-859.

10. Bhat S, Coleman HG, Yousef F, Johnston BT, McManus DT, Gavin AT, Murray LJ. Risk of malignant progression in Barrett's esophagus patients: results from a large population-based study. J Natl Cancer Inst 2011; 103: 1049-1057.

11. Hvid-Jensen F, Pedersen L, Drewes AM, Sørensen HT, Funch-Jensen P. Incidence of adenocarcinoma among patients with Barrett's esophagus. N Engl J Med 2011; 365: 1375-1383.

12. Polednak AP. Trends in survival for both histologic types of esophageal cancer in US surveillance, epidemiology and end results areas. Int J Cancer 2003; 105: 98-100.

13. Holmes RS, Vaughan TL. Epidemiology and pathogenesis of esophageal cancer. Semin Radiat Oncol 2007; 17: 2-9.

14. Wolf WA, Pasricha S, Cotton C, Li N, Triadafilopoulos G, Muthusamy VR, Chmielewski GW, Corbett FS, Camara DS, Lightdale CJ, Wolfsen $\mathrm{H}$, Chang $\mathrm{KJ}$, Overholt BF, Pruitt RE, Ertan A, Komanduri S, Infantolino A, Rothstein RI, Shaheen NJ. Incidence of esophageal adenocarcinoma and causes of mortality after radiofrequency ablation of Barrett's esophagus. Gastroenterology 2015; 149: 1752-1761e1.

15. Verbeek RE, Leenders M, ten Kate FJW, van Hillegersberg R, Vleggaar FP, van Baal JW, van Oijen MG, Siersema PD. Surveillance of Barrett's esophagus and mortality from esophageal adenocarcinoma: a population-based cohort study. Am J Gastroenterol 2014; 109: 1215-1222.

16. Al-Habbaa A, Rawla P, Morra ME, Abotaha AA, Sakr EE, Abdo Shehata MA, Shahin KM, Abdel Mageed S, Huy NT. Valvular involvement in granulomatosis with polyangiitis: case report and systematic review of literature. Echocardiography 2018; 35: 1456-1463.

17. Kim JY, Kim YS, Jung MK, Park JJ, Kang DH, Kim JS, Song CW, Lee SW, Bak YT. Prevalence of Barrett's esophagus in Korea. J Gastroenterol Hepatol 2005; 20: 633-636.

18. Ronkainen J, Aro P, Storskrubb T, Johansson SE, Lind T, Bolling-Sternevald E, Vieth M, Stolte M, Talley NJ, Agréus L. Prevalence of Barrett's esophagus in the general population: an endoscopic study. Gastroenterology 2005; 129 : 1825-1831.

19. Zeng H, Zheng R, Zhang S, Zuo T, Xia C, Zou X, Chen W. Esophageal cancer statistics in China, 2011: estimates based on 177 cancer registries. Thorac Cancer 2016; 7: 232-237.

20. Rex DK, Cummings OW, Shaw M, Cumings MD, Wong RK, Vasudeva RS, Dunne D, Rahmani EY, Helper DJ. Screening for Barrett's esophagus in colonoscopy 
patients with and without heartburn. Gastroenterology 2003; 125: 1670-1677.

21. Conio M, Cameron AJ, Romero Y, Branch CD, Schleck CD, Burgart LJ, Zinsmeister AR, Melton LJ $3^{\text {rd }}$, Locke GR $3^{\text {rd }}$. Secular trends in the epidemiology and outcome of Barrett's oesophagus in Olmsted County, Minnesota. Gut 2001; 48: 304-309.

22. Westhoff B, Brotze S, Weston A, McElhinney C, Cherian R, Mayo MS, Smith HJ, Sharma P. The frequency of Barrett's esophagus in high-risk patients with chronic GERD. Gastrointest Endosc 2005; 61: 226-231.

23. Magno P, Gonzalez L, Cruz-Correa M, Suarez E. The prevalence of Barrett's-esophagus-associated dysplasia in Puerto Rico. P R Health Sci J 2014; 33: 184-189.

24. Wani IR, Showkat HI, Bhargav DK, Samer M. Prevalence and risk factors for Barrett's esophagus in patients with GERD in Northern India: do methylene blue-directed biopsies improve detection of Barrett's esophagus compared the conventional method? Middle East J Dig Dis 2014; 6: 228-236.

25. Hayeck TJ, Kong CY, Spechler SJ, Gazelle GS, Hur C. The prevalence of Barrett's esophagus in the US: estimates from a simulation model confirmed by SEER data. Dis Esophagus 2010; 23: 451-457.

26. Ward EM, Wolfsen HC, Achem SR, Loeb DS, Krishna M Hemminger LL, DeVault KR. Barrett's esophagus is common in older men and women undergoing screening colonoscopy regardless of reflux symptoms. Am J Gastroenterol 2006; 101: 12-17.

27. Rawla P, Bandaru SS, Vellipuram AR. Review of infectious etiology of acute pancreatitis. Gastroenterology Res 2017; 10: 153-158.

28. Masclee GM, Coloma PM, de Wilde M, Kuipers EJ, Sturkenboom MC. The incidence of Barrett's oesophagus and oesophageal adenocarcinoma in the United Kingdom and the Netherlands is levelling off. Aliment Pharmacol Ther 2014; 39: 1321-1330.

29. van Soest EM, Dieleman JP, Siersema PD, Sturkenboom MC, Kuipers EJ. Increasing incidence of Barrett's oesophagus in the general population. Gut 2005; 54: 1062-1066.

30. Cameron AJ, Zinsmeister AR, Ballard DJ, Carney JA. Prevalence of columnar-lined (Barrett's) esophagus. Comparison of population-based clinical and autopsy findings. Gastroenterology 1990; 99: 918-922.

31. Fock KM, Ang TL. Global epidemiology of Barrett's esophagus. Expert Rev Gastroenterol Hepatol 2011; 5: 123-130.

32. Falk GW, Jacobson BC, Riddell RH, Rubenstein JH, ElZimaity H, Drewes AM, Roark KS, Sontag SJ, Schnell TG, Leya J, Chejfec G, Richter JE, Jenkins G, Goldman A, Dvorak K, Nardone G. Barrett's esophagus: prevalenceincidence and etiology-origins. Ann N Y Acad Sci 2011; 1232: 1-17.

33. Modiano N, Gerson LB. Barrett's esophagus: incidence, etiology, pathophysiology, prevention and treatment. Ther Clin Risk Manag 2007; 3: 1035-1145.

34. Musana AK, Resnick JM, Torbey CF, Mukesh BN, Greenlee RT. Barrett's esophagus: incidence and prevalence estimates in a rural Mid-Western population. Am J Gastroenterol 2008; 103: 516-524.

35. van Blankenstein M, Looman CW, Johnston BJ, Caygill CP. Age and sex distribution of the prevalence of Barrett's esophagus found in a primary referral endoscopy center. Am J Gastroenterol 2005; 100: 568-576.

36. Spechler SJ. Barrett's esophagus and esophageal adenocarcinoma: pathogenesis, diagnosis, and therapy. Med Clin North Am 2002; 86: 1423-1445, vii.

37. Kramer JR, Fischbach LA, Richardson P, Alsarraj A, Fitzgerald S, Shaib Y, Abraham NS, Velez M, Cole R, Anand B, Verstovsek G, Rugge M, Parente P, Graham DY, ElSerag HB. Waist-to-hip ratio, but not body mass index, is associated with an increased risk of Barrett's esophagus in white men. Clin Gastroenterol Hepatol 2013; 11: 373381e1.

38. Ford AC, Forman D, Reynolds PD, Cooper BT, Moayyedi P. Ethnicity, gender, and socioeconomic status as risk factors for esophagitis and Barrett's esophagus. Am J Epidemiol 2005; 162: 454-460.

39. Abrams JA, Fields S, Lightdale CJ, Neugut AI. Racial and ethnic disparities in the prevalence of Barrett's esophagus among patients who undergo upper endoscopy. Clin Gastroenterol Hepatol 2008; 6: 30-34.

40. Rawla P, Sunkara T, Muralidharan P, Raj JP. Update in global trends and aetiology of hepatocellular carcinoma. Contemp Oncol (Pozn) 2018; 22: 141-150.

41. Bray F, Ferlay J, Soerjomataram I, Siegel RL, Torre LA, Jemal A. Global cancer statistics 2018: GLOBOCAN estimates of incidence and mortality worldwide for 36 cancers in 185 countries. CA Cancer J Clin 2018; 68: 394-424.

42. Samarasam I. Esophageal cancer in India: current status and future perspectives. Int J Adv Med Health Res 2017; 4: 5-10.

43. Rawla P, Vellipuram AR, Bandaru SS, Pradeep Raj J. Colon carcinoma presenting as Streptococcus anginosus bacteremia and liver abscess. Gastroenterology Res 2017; 10: 376-379.

44. Arnold M, Soerjomataram I, Ferlay J, Forman D. Global incidence of oesophageal cancer by histological subtype in 2012. Gut 2015; 64: 381-387.

45. Pohl H, Sirovich B, Welch HG. Esophageal adenocarcinoma incidence: are we reaching the peak? Cancer Epidemiol Biomarkers Prev 2010; 19: 1468-1470.

46. Arnold M, Laversanne M, Brown LM, Devesa SS, Bray F. Predicting the future burden of esophageal cancer by histological subtype: international trends in incidence up to 2030. Am J Gastroenterol 2017; 112: 1247-1255.

47. Hur C, Miller M, Kong CY, Dowling EC, Nattinger KJ, Dunn M, Feuer EJ. Trends in esophageal adenocarcinoma incidence and mortality. Cancer 2013; 119: 1149-1158.

48. Nordenstedt H, El-Serag $\mathrm{H}$. The influence of age, sex, and race on the incidence of esophageal cancer in the United States (1992-2006). Scand J Gastroenterol 2011; 46: 597602.

49. Cook MB, Chow WH, Devesa SS. Oesophageal cancer incidence in the United States by race, sex, and histologic type, 1977-2005. Br J Cancer 2009; 101: 855-859.

50. Cen P, Banki F, Cheng L, Khalil K, Du XL, Fallon M, Amato RJ, Kaiser LR. Changes in age, stage distribution, and survival of patients with esophageal adenocarcinoma over three decades in the United States. Ann Surg Oncol 2012; 19: 1685-1691.

51. Njei B, McCarty TR, Birk JW. Trends in esophageal cancer survival in United States adults from 1973 to 2009: a SEER database analysis. J Gastroenterol Hepatol 2016; 31: 11411146. 
52. Anderson LA, Tavilla A, Brenner H, Luttmann S, Navarro C, Gavin AT, Holleczek B, Johnston BT, Cook MB, Bannon F, Sant M; EUROCARE-5 Working Group:. Survival for oesophageal, stomach and small intestine cancers in Europe 1999-2007: results from EUROCARE-5. Eur J Cancer 2015; 51: 2144-2157.

53. Zeng H, Zheng R, Guo Y, Zhang S, Zou X, Wang N, Zhang L, Tang J, Chen J, Wei K, Huang S, Wang J, Yu L, Zhao D, Song G, Chen J, Shen Y, Yang X, Gu X, Jin F, Li Q, Li Y, Ge H, Zhu F, Dong J, Guo G, Wu M, Du L, Sun X, He Y, Coleman MP, Baade P, Chen W, Yu XQ. Cancer survival in China, 2003-2005: a population-based study. Int J Cancer 2015; 136: 1921-1930.

54. Kauppila JH, Mattsson F, Brusselaers N, Lagergren J. Prognosis of oesophageal adenocarcinoma and squamous cell carcinoma following surgery and no surgery in a nationwide Swedish cohort study. BMJ Open 2018; 8: e021495.

55. Wong A, Fitzgerald RC. Epidemiologic risk factors for Barrett's esophagus and associated adenocarcinoma. Clin Gastroenterol Hepatol 2005; 3: 1-10.

56. de Jonge PJ, van Blankenstein M, Grady WM, Kuipers EJ. Barrett's oesophagus: epidemiology, cancer risk and implications for management. Gut 2014; 63: 191-202.

57. Schlottmann F, Molena D, Patti MG. Gastroesophageal reflux and Barrett's esophagus: a pathway to esophageal adenocarcinoma. Updates Surg 2018; 70: 339-342.

58. Rawla P, Sunkara T, Raj JP. Updated review of current pharmacological and non-pharmacological management of irritable bowel syndrome. Life Sci 2018; 212: 176-181.

59. Rubenstein JH, Taylor JB. Meta-analysis: the association of oesophageal adenocarcinoma with symptoms of gastro-oesophageal reflux. Aliment Pharmacol Ther 2010; 32: 1222-1227.

60. Cook MB, Corley DA, Murray LJ, Liao LM, Kamangar F, Ye W, Gammon MD, Risch HA, Casson AG, Freedman ND, Chow WH, Wu AH, Bernstein L, Nyrén O, Pandeya N, Whiteman DC, Vaughan TL. Gastroesophageal reflux in relation to adenocarcinomas of the esophagus: a pooled analysis from the Barrett's and Esophageal Adenocarcinoma Consortium (BEACON). PLoS One 2014; 9 : e103508.

61. Thrift AP, Kramer JR, Qureshi Z, Richardson PA, ElSerag HB. Age at onset of GERD symptoms predicts risk of Barrett's esophagus. Am J Gastroenterol 2013; 108: 915-922.

62. Cook MB, Kamangar F, Whiteman DC, Freedman ND, Gammon MD, Bernstein L, Brown LM, Risch HA, Ye W, Sharp L, Pandeya N, Webb PM, Wu AH, Ward MH, Giffen C, Casson AG, Abnet CC, Murray LJ, Corley DA, Nyrén $\mathrm{O}$, Vaughan $\mathrm{TL}$, Chow $\mathrm{WH}$. Cigarette smoking and adenocarcinomas of the esophagus and esophagogastric junction: a pooled analysis from the international BEACON consortium. J Natl Cancer Inst 2010; 102: 13441353.

63. Tramacere I, La Vecchia C, Negri E. Tobacco smoking and esophageal and gastric cardia adenocarcinoma: a metaanalysis. Epidemiology 2011; 22: 344-349.

64. Wang QL, Xie SH, Li WT, Lagergren J. Smoking cessation and risk of esophageal cancer by histological type: systematic review and meta-analysis. J Natl Cancer Inst 2017; 109. doi: 10.1093/jnci/djx115.

65. Tramacere I, Pelucchi C, Bagnardi V, Rota M, Scotti L, Islami F, Corrao G, Boffetta P, La Vecchia C, Negri E. A meta- analysis on alcohol drinking and esophageal and gastric cardia adenocarcinoma risk. Ann Oncol 2012; 23: 287-297.

66. Thrift AP, Cook MB, Vaughan TL, Anderson LA, Murray LJ, Whiteman DC, Shaheen NJ, Corley DA. Alcohol and the risk of Barrett's esophagus: a pooled analysis from the International BEACON Consortium. Am J Gastroenterol 2014; 109: 1586-1594.

67. Rawla P, Sunkara T, Raj JP. Role of biologics and biosimilars in inflammatory bowel disease: current trends and future perspectives. J Inflamm Res 2018; 11: 215-226.

68. Ogden CL, Carroll MD, Kit BK, Flegal KM. Prevalence of childhood and adult obesity in the United States, 20112012. JAMA 2014; 311: 806-814.

69. Kamat P, Wen S, Morris J, Anandasabapathy S. Exploring the association between elevated body mass index and Barrett's esophagus: a systematic review and meta-analysis. Ann Thorac Surg 2009; 87: 655-662.

70. Lauby-Secretan B, Scoccianti C, Loomis D, Grosse Y, Bianchini F, Straif K; International Agency for Research on Cancer Handbook Working Group. Body fatness and cancer: viewpoint of the IARC Working Group. N Engl J Med 2016; 375: 794-798.

71. Thrift AP, Shaheen NJ, Gammon MD, Bernstein L, Reid BJ, Onstad L, Risch HA, Liu G, Bird NC, Wu AH2, Corley DA, Romero Y, Chanock SJ, Chow WH, Casson AG, Levine DM, Zhang R, Ek WE, MacGregor S, Ye W, Hardie LJ, Vaughan TL, Whiteman DC. Obesity and risk of esophageal adenocarcinoma and Barrett's esophagus: a Mendelian randomization study. J Natl Cancer Inst 2014; 106: pii: dju252. doi: 10.1093/jnci/dju252.

72. Hoyo C, Cook MB, Kamangar F, Freedman ND, Whiteman DC, Bernstein L, Brown LM, Risch HA, Ye W, Sharp L, Wu AH, Ward MH, Casson AG, Murray LJ, Corley DA, Nyrén O, Pandeya N, Vaughan TL, Chow WH, Gammon MD. Body mass index in relation to oesophageal and oesophagogastric junction adenocarcinomas: a pooled analysis from the International BEACON Consortium. Int J Epidemiol 2012; 41: 1706-1718.

73. Rawla P, Barsouk A. Epidemiology of gastric cancer: global trends, risk factors and prevention. Gastroenterology Rev 2019; 14: 26-38.

74. Drahos J, Ricker W, Pfeiffer RM, Cook MB. Metabolic syndrome and risk of esophageal adenocarcinoma in elderly patients in the United States: an analysis of SEER-Medicare data. Cancer 2017; 123: 657-665.

75. Petrick JL, Kelly SP, Liao LM, Freedman ND, Graubard BI, Cook MB. Body weight trajectories and risk of oesophageal and gastric cardia adenocarcinomas: a pooled analysis of NIH-AARP and PLCO Studies. Br J Cancer 2017; 116: 951-959.

76. Lagergren J. Influence of obesity on the risk of esophageal disorders. Nat Rev Gastroenterol Hepatol 2011; 8: 340-347.

77. Chandar AK, Iyer PG. Role of obesity in the pathogenesis and progression of Barrett's esophagus. Gastroenterol Clin North Am 2015; 44: 249-264.

78. Kubo A, Cook MB, Shaheen NJ, Vaughan TL, Whiteman DC, Murray L, Corley DA. Sex-specific associations between body mass index, waist circumference and the risk of Barrett's oesophagus: a pooled analysis from the international BEACON consortium. Gut 2013; 62: 16841691. 
79. Rawla P, Sunkara T, Thandra KC, Gaduputi V. Hypertriglyceridemia-induced pancreatitis: updated review of current treatment and preventive strategies. Clin J Gastroenterol 2018; 11: 441-448.

80. El-Serag HB, Hashmi A, Garcia J, Richardson P, Alsarraj A, Fitzgerald S, Vela M, Shaib Y, Abraham NS, Velez M, Cole R, Rodriguez MB, Anand B, Graham DY, Kramer JR. Visceral abdominal obesity measured by CT scan is associated with an increased risk of Barrett's oesophagus: a case-control study. Gut 2014; 63: 220-229.

81. Nie S, Chen T, Yang X, Huai P, Lu M. Association of Helicobacter pylori infection with esophageal adenocarcinoma and squamous cell carcinoma: a meta-analysis. Dis Esophagus 2014; 27: 645-653.

82. Rokkas T, Pistiolas D, Sechopoulos P, Robotis I, Margantinis G. Relationship between Helicobacter pylori infection and esophageal neoplasia: a meta-analysis. Clin Gastroenterol Hepatol 2007; 5: 1413-1417, 1417e1-2.

83. Wang Z, Shaheen NJ, Whiteman DC, Anderson LA, Vaughan TL, Corley DA, El-Serag HB, Rubenstein JH, Thrift AP. Helicobacter pylori infection is associated with reduced risk of Barrett's esophagus: an analysis of the Barrett's and Esophageal Adenocarcinoma Consortium. Am J Gastroenterol 2018; 113: 1148-1155.

84. Vaughan TL, Dong LM, Blount PL, Ayub K, Odze RD, Sanchez CA, Rabinovitch PS, Reid BJ. Non-steroidal anti-inflammatory drugs and risk of neoplastic progression in Barrett's oesophagus: a prospective study. Lancet Oncol 2005; 6: 945-952.

85. Liao LM, Vaughan TL, Corley DA, Cook MB, Casson AG, Kamangar F, Abnet CC, Risch HA, Giffen C, Freedman ND, Chow WH, Sadeghi S, Pandeya N, Whiteman DC, Murray LJ, Bernstein L, Gammon MD, Wu AH. Nonsteroidal anti-inflammatory drug use reduces risk of adenocarcinomas of the esophagus and esophagogastric junction in a pooled analysis. Gastroenterology 2012; 142: 442-452 e445.

86. Thrift AP, Anderson LA, Murray LJ, Cook MB, Shaheen NJ, Rubenstein JH, El-Serag HB, Vaughan TL, Schneider JL, Whiteman DC, Corley DA. Nonsteroidal anti-inflammatory drug use is not associated with reduced risk of Barrett's esophagus. Am J Gastroenterol 2016; 111: 1528-1535.

87. Alexandre L, Clark AB, Bhutta HY, Holt S, Lewis MP, Hart AR. Statin use is associated with reduced risk of histologic subtypes of esophageal cancer: a nested case-control analysis. Gastroenterology 2014; 146: 661-668.

88. Thomas T, Loke Y, Beales ILP. Systematic review and meta-analysis: use of statins is associated with a reduced incidence of oesophageal adenocarcinoma. J Gastrointest Cancer 2018; 49: 442-454.

89. Nguyen T, Duan Z, Naik AD, Kramer JR, El-Serag HB. Statin use reduces risk of esophageal adenocarcinoma in US veterans with Barrett's esophagus: a nested case-control study. Gastroenterology 2015; 149: 1392-1398.

90. Rawla P, Pradeep Raj J, Thandra KC, Bandaru SS. Superior mesenteric vein thrombosis in a patient on oral contraceptive pills. Gastroenterology Res 2017; 10: 380-382.

91. Lagergren J, Bergstrom R, Adami HO, Nyren O. Association between medications that relax the lower esophageal sphincter and risk for esophageal adenocarcinoma. Ann Intern Med 2000; 133: 165-175.
92. Rawla P, Raj JP. Doxycycline-induced acute pancreatitis: a rare adverse event. Gastroenterology Res 2017; 10: 244246.

93. Singh S, Garg SK, Singh PP, Iyer PG, El-Serag HB. Acidsuppressive medications and risk of oesophageal adenocarcinoma in patients with Barrett's oesophagus: a systematic review and meta-analysis. Gut 2014; 63: 1229-1237.

94. El-Serag HB, Aguirre TV, Davis S, Kuebeler M, Bhattacharyya A, Sampliner RE. Proton pump inhibitors are associated with reduced incidence of dysplasia in Barrett's esophagus. Am J Gastroenterol 2004; 99: 1877-1883.

95. Kastelein F, Spaander MC, Steyerberg EW, Biermann K, Valkhoff VE, Kuipers EJ, Bruno MJ; ProBar Study Group. Proton pump inhibitors reduce the risk of neoplastic progression in patients with Barrett's esophagus. Clin Gastroenterol Hepatol 2013; 11: 382-388.

96. Hu Q, Sun TT, Hong J, Fang JY, Xiong H, Meltzer SJ. Proton pump inhibitors do not reduce the risk of esophageal adenocarcinoma in patients with Barrett's esophagus: a systematic review and meta-analysis. PLoS One 2017; 12: $\mathrm{e} 0169691$.

97. Wysowski DK. Reports of esophageal cancer with oral bisphosphonate use. N Engl J Med 2009; 360: 89-90.

98. Cardwell CR, Abnet CC, Cantwell MM, Murray LJ. Exposure to oral bisphosphonates and risk of esophageal cancer. JAMA 2010; 304: 657-663.

\section{Address for correspondence:}

\section{Nancy Perez MD}

Department of Gastroenterology

St. Joseph Medical Center

University of Washington

WA, USA

E-mail: nancyper365@gmail.com 